\title{
EFIKASI DIRI DAN KEMAMPUAN LITERASI INFORMASI PADA GURU SEKOLAH MENENGAH ATAS
}

Lussy Dwiutami*

*Program Studi Psikologi, Universitas Negeri Jakarta

** Program Studi Psikologi, Universitas Negeri Jakarta

DOI: https://doi.org/10.21009/JPPP.042.04

\section{Alamat Korespondensi:}

lussysf@unj.ac.id
Tantri Dwinantika Wardi** 
atau pengaksesan sekolah, acceptability atau penerimaan pada seluruh lapisan masayarakat, dan adaptability atau adaptasi dengan wilayah sekitar), sekolah yang belum ramah anak atau acceptability, dan akses bagi kelompok-kelompok marginal atau adaptability.

Indikator-indikator tersebut menggambarkan bahwa faktor guru, sekolah yang ramah anak, dan akses yang belum merata menyebabkan pendidikan Indonesia masih belum mampu menyaingi negara-negara berkembang lainnya. Guru sebagai salah satu motor penggerak pendidikan di Indonesia diharapkan memiliki beberapa kompetensi yang akan membantu guru untuk mewujudkan tujuan pendidikan di Indonesia. Berdasarkan Peraturan Pemerintah Nomor 74 Tahun 2008 Tentang Guru Pasal 3 ayat 2, kompetensikompetensi tersebut meliputi (a) kompetensi pedagogik, (b) kompetensi kepribadian, (c) kompetensi sosial, dan (d) kompetensi profesional. Kompetensi pendagogik meliputi kemampuan guru dalam mengelola peserta didik beserta program pembelajaran, kompetensi kepribadian mencakup kemampuan personal dan kepribadian guru yang ideal, kompetensi sosial terkait dengan keterampilan guru dalam berintaksi dengan lingkungannya, dan kompetensi profesional mencakup penguasaan materi pelajaran yang disusun dalam kurikulum serta substansi keilmuan dan struktur berserta metodologi keilmuan (Muzdalifah \& Listyasari, 2013).

Kurikulum yang saat ini dipakai di sekolahsekolah adalah kurikulum 2013, yaitu kurikulum terbaru yang disusun pemerintah dengan harapan dapat menyempurnakan kurikulum terdahulu. Kurikulum ini lebih menekankan pada aspek softskill dan hardskill dengan tujuan untuk menyeimbangkan kompetensi sikap, keterampilan, dan pengetahuan peserta didik (Fadhilah, 2014 dalam Putri, 2015). Kurikulum 2013 menuntut peserta didik untuk lebih aktif dalam pembelajaran dan menjadikan guru sebagai fasilitator dalam menyediakan pengalaman untuk merangsang keaktifan peserta didik melalui kegiatan-kegiatan yang dapat mengembangkan potensi yang dimiliki, dalam upaya menghadapi tantangan di masa depan baik di masyarakat, lingkungan pekerjaan maupun dunia pendidikan yang lebih tinggi (Permendikbud No. 69 Tahun
2013). Untuk itu, guru sebagai penyedia pengalaman bagi peserta didik juga dituntut untuk selalu berwawasan dan kreatif dalam menyelenggarakan pembelajaran, terutama guru pada jenjang dimana murid akan memasuki dunia perguruan tinggi maupun lingkungan pekerjaan setelah lulus dari sekolah. Guru pada jenjang ini diharapkan mampu untuk lebih memfasilitasi murid dalam mengembangkan potensinya melalui pembelajaran dalam kelas yang mengacu pada kurikulum. Hal ini karena dalam dunia pekerjaan dan perguruan tinggi diperlukan seseorang yang mampu berwawasan secara luas dan mampu mengatasi berbagai permasalahan yang akan dihadapi nantinya.

Dalam era modernisasi seperti sekarang, tidaklah sulit untuk mencari informasi guna menyokong terwujudnya pendidikan yang baik. Namun, tidak semua informasi yang tersedia merupakan informasi yang benar, objektif, dan dapat dipertanggungjawabkan. Diperlukan suatu keahlian atau skill untuk menyaring informasi yang ada yang disebut dengan kemampuan literasi informasi. Tetapi pada kenyataannya, tingkat keterbacaan di Indonesia masih membutuhkan banyak perhatian. Data yang dikumpulkan oleh Programme for International Student Assessment (PISA) pada tahun 2012 menyebutkan bahwa minat membaca masyarakat Indonesia rendah bila dibandingkan dengan negara-negara lain. Indonesia berada di peringkat 60 dari 65 negara yang diteliti. Sementara tingkat buta huruf di Indonesia masih cukup tinggi, dengan 5.984.075 orang yang tercatat tidak dapat membaca dan menulis. Dengan data-data tersebut, kemampuan literasi informasi memiliki tingkat urgensi yang cukup signifikan dalam membantu menyelesaikan persoalan-persoalan yang terdapat di masyarakat.

Literasi informasi memiliki banyak definisi dan konsep. Namun secara umum, literasi informasi dapat dikatakan sebagai cara seseorang untuk menemukan, mengidentifikasi, mengolah, menyaring, mengevaluasi, dan menggunakan informasi secara efektif untuk menyelesaikan permasalahan yang dihadapi. American Librarian Association (2000) merumuskan literasi informasi sebagai "set of skills that enables the ability to recognize the need for information, and the ability to search for, access, evaluate, and use information to fulfill a specific purpose" (dalam 
Wertz, Fosmire, Purzer, Saragih, Van Epps, Sapp Nelson, \& Dillman, 2013).

Menurut modul Kurikulum 2013 untuk Sekolah Dasar, literasi informasi merupakan keterampilan berpikir menggunakan sumber-sumber pengetahuan dalam bentuk cetak, visual, digital, dan auditori. Ferguson (www.bibliotech.us/pdfs/ InfoLit.pdf) menyebutkan bahwa literasi informasi terdiri dari lima komponen, yaitu (a) Literasi Dasar atau Basic Literacy, (b) Literasi Perpustakaan atau Library Literacy, (c) Literasi Media atau Media Literacy, (d) Literasi Teknologi atau Technology Literacy, dan (e) Literasi Visual atau Visual Literacy.

Literasi informasi sangat erat kaitannya dengan berpikir kritis (Wertz, Fosmire, Purzer, Saragih, Van Epps, Sapp Nelson, \& Dillman, 2013) dan keduanya dapat mempengaruhi performa akademis dan kemampuan menulis siswa. Dengan literasi informasi, guru juga dapat mengembangkan keterampilan literasi informasi yang lebih dalam, seperti literasi data atau Data Literacy for Teacher (DLFT). Dengan DLFT ini, guru dapat menggunakan informasi atau data yang ada, seperti asesmen, iklim sekolah, behavioral, snapshot, informasi jangka panjang (longitudinal), moment-to-moment, dan mengubahnya menjadi pengetahuan yang instruksional dan praktikal.

Untuk dapat menggunakan kemampuan dan kompetensi dengan baik, seseorang harus memiliki keyakinan bahwa dirinya mampu melakukan suatu hal dengan baik pula. Teori tentang efikasi guru merujuk pada teori Albert Bandura mengenai kekuatan berpikir positif yang dikenal dengan self-efficacy atau efikasi diri, yaitu sebuah perasaan akan kemampuan kita dalam mengerjakan suatu tugas (Myers, 2012). Dalam kaitannya dengan guru, efikasi diri merujuk pada kepercayaan diri guru akan kemampuan mereka untuk meningkatkan kemampuan belajar siswa (Hoy, 2000 dalam Prothero, 2008). Lebih lanjut Myers (2012) mengatakan bahwa anak-anak dan orang dewasa yang memiliki tingkat efikasi diri yang tinggi lebih pantang menyerah, tidak mudah cemas dan tertekan, menjalani hidup yang lebih sehat dan berprestasi secara akademik. Hal ini juga berlaku bagi guru. Berdasarkan beberapa penelitian, efikasi diri yang dimiliki oleh guru memiliki keterkaitan dengan performa mengajarnya. Guru yang memiliki harga diri dan efikasi diri secara umum yang rendah mengarah pada rendahnya efikasi diri guru dan berakibat pada performa mengajarnya, begitu pula sebaliknya (Khan, Fleva, \& Qazi, 2015). Performa di kelas yang memuaskan juga memiliki korelasi yang positif dengan efikasi diri guru (TschannenMoran \& Hoy, 2007 dalam Ozder, 2011). Hal ini dikarenakan efikasi yang dimiliki oleh guru memengaruhi besarnya upaya yang diberikan, tujuan pengajaran yang ditargetkan, serta berpengaruh pada level aspirasi guru dalam mengajar (Muzdalifah \& Listyasari, 2013). Semakin tinggi upaya, target pembelajaran, serta level aspirasi guru, semakin tinggi pula performa yang dihasilkan oleh guru tersebut.

Efikasi guru juga merupakan salah satu konstruk psikologis yang memiliki kekuatan prediksi terbaik bagi kemampuan siswa seperti prestasi belajar, motivasi, serta keyakinan diri pada siswa (Muzdalifah \& Listyasari, 2013). Hal ini dibuktikan dengan penelitian yang dilakukan Syah (1995) yang menyatakan bahwa terdapat korelasi yang positif dan signifikan antara keyakinan terhadap kemampuan pribadi guru dan calon guru dalam membangkitkan minat belajar siswa dengan hasil belajar siswa (dalam Muzdalifah \& Listyasari, 2013). Jadi, apabila seorang guru yakin bahwa ia mampu meningkatkan minat belajar siswa, prestasi akademik siswa pun juga akan ikut bertambah. Efikasi diri yang kuat pada guru juga membawa dampak hubungan antara guru dan siswa ke arah yang lebih positif. Hubungan tersebut berupa adanya perasaan dekat dengan guru dan merasa lebih mudah berko-munikasi dengan guru mereka. Efikasi guru juga dapat mempengaruhi cara managemen kelas (Gurcay, 2015). Dalam penelitiannya dikatakan bahwa guru dengan efikasi yang tinggi dapat mengatur stres personal sehingga pengaturan pada kelas juga akan ikut berdampak.

Muzdalifah dan Listyasari (2013) juga menjelaskan bahwa guru dengan efikasi yang tinggi juga mudah terbuka dengan banyak gagasan, bahkan tidak jarang mereka berani mencoba mengeksplorasi metode-metode pembelajaran. Dengan adanya tingkat efikasi yang tinggi, guru 
menjadi lebih peka terhadap informasi di sekelilingnya dan membantu guru untuk melakukan literasi informasi.

Untuk memperkuat bahwa efikasi diri dan kemampuan literasi informasi menjadi suatu aspek yang penting bagi guru, dilakukan wawancara kepada guru. $\mathrm{Z}$ merupakan seorang guru yang telah 33 tahun mengajar di salah satu sekolah menengah kejuruan di Jakarta. Meskipun $\mathrm{Z}$ telah pensiun pada tahun 2015 lalu, namun pengalamannya dalam mengajar masih relevan untuk dijadikan sumber data awal. Dari hasil wawancara, $\mathrm{Z}$ mengaku bahwa tidak begitu terasa perbedaannya antara mengajar di kurikulum 2013 maupun di kurikulum sebelumnya. Mungkin ini disebabkan karena ia mengajar di mata pelajaran yang menyangkut praktik sehingga perubahan itu tidak terasa. Dalam pencarian buku ajar berdasarkan silabus, $\mathrm{Z}$ mencari beberapa buku tambahan untuk pelengkap buku yang sudah disediakan di sekolah. Pencarian buku juga hanya berdasar pada subbab-subbab materi yang ada di silabus. Jika ada buku yang sesuai langsung diaplikasikan ke kelas dan jika sudah merasa cocok langsung dipakai di kelas. Mengenai efikasi diri dalam mengajar, $\mathrm{Z}$ merasa yakin bahwa ia telah mengajar dengan baik dan materi yang disampaikan juga sudah sesuai. $\mathrm{Z}$ merasa yakin telah mengajar dengan baik berdasarkan hasil yang didapatkan dari si anak.

Berdasarkan wawancara tersebut dapat disimpulkan bahwa antara efikasi diri dalam mengajar serta kemampuan literasi informasi memiliki suatu peran tersendiri. Pada guru tersebut dapat dilihat bahwa keyakinan dirinya cukup tinggi, dilihat dari penjelasan-penjelasan yang diberikan. Hal ini dapat disebabkan oleh pengalaman mengajar guru yang cukup lama. Bandura (1995) menyatakan bahwa salah satu sumber munculnya efikasi diri adalah mastery experience, di mana semakin berpengalaman seseorang semakin tinggi efikasi dirinya. Namun tingginya efikasi diri tersebut tidak dibarengi dengan kemampuan literasi informasinya. Guru tersebut tidak begitu banyak mengeksplor sumber-sumber informasi untuk dijadikan bahan ajar atau referensi metode mengajar. Perbedaan ini mungkin disebabkan oleh lingkungan sekolah yang tidak terlalu menuntut guru untuk mencoba hal baru. Seperti yang telah dijelaskan Z, kurikulum 2013 yang diterapkan di sekolah tidak begitu terasa perbedaannya dengan kurikulum yang sebelumnya diterapkan di sekolah. Namun, meskipun kemampuan literasi informasi tidak terlalu tinggi seperti efikasi yang dimiliki Z, kemampuan tersebut tetap ada. Z tetap mencari sumber ajar dari beberapa sumber walau tidak terlalu beragam. Hasil wawancara juga dapat disimpulkan terjadi pula pada guru-guru yang mengajar di jenjang yang setara dengan sekolah menengah kejuruan, yaitu sekolah menengah atas karena mengingat tidak terlalu banyak perbedaan dalam hal kurikulum dan tuntutan pengajaran. Hal ini dapat dijadikan acuan bahwa apakah memang efikasi diri dan literasi informasi ini memang terdapat hubungan yang signifikan atau tidak. khususnya pada guru yang mengajar di sekolah mengenah atas karena melihat hasil preliminary study yang menggunakan guru sekolah menengah atas, dalam hal ini kejuruan, sebagai sumber.

Melihat betapa pentingnya efikasi diri pada guru serta kemampuan literasi informasi bagi guru, maka penelitian ini bertujuan untuk melihat apakah terdapat hubungan antara efikasi diri dengan kemampuan literasi informasi pada guru sekolah menengah atas.

\section{Metode Penelitian}

Penelitian ini menggunakan pendekatan kuantitatif di mana data disajikan berupa angka dan dianalisis dengan teknik statistika inferensial. Berdasarkan karakteristik masalah yang diteliti, penelitian ini termasuk pada penelitian korelasional, yaitu tipe penelitian dengan karakteristik masalah berupa hubungan korelasional antara dua variabel atau lebih (Sangadji \& Sopiah, 2010). Penelitian ini termasuk ke dalam penelitian korelasi di mana penelitian melibatkan tindakan pengumpulan data guna menentukan apakah ada hubungan dan tingkat hubungan antara dua variabel atau lebih (F.C., Dane, 2000 dalam Sangadji \& Sopiah, 2010).

Populasi dalam peneltiian ini adalah guru SMA yang mengajar di sekolah dengan kurikulum kurikulum 2013 di wilayah DKI Jakarta dengan prosedur teknik sampling yang digunakan adalah nonprobability sampling, yaitu teknik yang tidak memberi peluang/kesempatan sama bagi setiap 
unsur atau anggota populasi untuk menjadi sampel (Sugiyono, 2011). Jenis teknik sampling dalam penelitian ini adalah kuota sampling. Kuota sampling adalah teknik untuk menentukan sampel dari populasi yang mempunyai ciri-ciri tertentu sampai jumlah (kuota) yang diinginkan (Sugiyono, 2011). Jumlah kuota yang diinginkan pada penelitian ini sebesar 100 orang. Penentuan jumlah kuota ini dibantu dengan menggunakan teknik sample size pada www.raosoft.com. Dengan menggunakan aplikasi ini, kita hanya perlu memasukkan besarnya margin eror, confidence level, besarnya populasi, dan response distribution pada kotak yang telah disediakan sehingga muncul jumlah sampel yang disarankan. Jika kita tidak mengetahui jumlah populasi dari sampel yang ingin kita ambil, maka aplikasi ini menyarankan untuk memasukkan angka 20.000 pada kotak. Hal ini karena ukuran sampel tidak akan berubah banyak untuk populasi yang lebih besar dari 20.000. Begitu pula dengan response distribution. Jika kita tidak mengetahui besaran distribusi respon, aplikasi ini menyarankan untuk memasukkan angka 50\%. Untuk penelitian ini, besarnya margin error sebesar $9.85 \%$, confidence level sebesar 95\%, besarnya populasi adalah 20.000 dan response distribution sebesar 50\%.

Teknik pengumpulan data yang digunakan pada penelitian ini adalah dengan menggunakan skala dengan dua jenis skala untuk pengukuran dua variabel. Untuk efikasi guru digunakan skala yang diadaptasi dari skala teacher efficacy milik Tschannen-Moran dan Woolfolk Hoy yaitu
Teacher Sense Efficacy Scale (TSES) yang dibuat pada tahun 2001. Skala ini terdiri dari 24 pertanyaan dengan skala rating 9-poin. Pada tahun 2011 skala ini telah dialihbahasakan dari Bahasa Inggris ke Bahasa Indonesia oleh Maula dan Rangkuti. Skala ini diuji coba pada 44 guru SMA di DKI Jakarta dengan Kurikulum 2013 dan menghasilkan nilai reliabilitas sebesar 0.64 dan aitem yang drop sebanyak 4 butir.

Untuk mengukur literasi informasi, digunakan skala yang diadaptasi berdasarkan skala yang dibuat oleh Tina Lisa Putri pada tahun 2013. Skala ini disusun berdasarkan teori The Big6 Model yang dikembangkan oleh Michael B. Eisenberg dan Robert E. Berkowitz pada tahun 1987. Jumlah aitem yang terdapat pada skala berjumlah 40 aitem yang kemudian dimodifikasi menjadi 42 aitem. Skala ini diuji coba pada 44 guru SMA di DKI Jakarta dengan Kurikulum 2013 dan menghasilkan nilai reliabilitas sebesar 0.90 dan item yang drop sebanyak 9 butir.

\section{Hasil Penelitian dan Diskusi}

Responden yang digunakan pada penelitian ini berjumlah 100 orang, sesuai dengan kuota yang telah ditentukan. Gambaran responden penelitian ini menunjukkan bahwa responden tergolong dalam usia dewasa awal dan dewasa tengah. Dalam tabel 1 dapat terlihat bahwa jumlah usia tertinggi berada pada rentang usia 48 hingga 52 tahun $(29 \%)$.

Tabel 1. Gambaran Usia Responden

\begin{tabular}{cccc}
\hline No & Rentang Usia & Jumlah & Persentase \\
\hline 1 & $23-27$ & 6 & $6 \%$ \\
\hline 2 & $28-32$ & 1 & $1 \%$ \\
\hline 3 & $33-37$ & 3 & $3 \%$ \\
\hline 4 & $38-42$ & 9 & $9 \%$ \\
\hline 5 & $43-47$ & 14 & $14 \%$ \\
\hline 6 & $48-52$ & 29 & $29 \%$ \\
\hline 7 & $53-57$ & 28 & $28 \%$ \\
\hline 8 & $58-62$ & 9 & $9 \%$ \\
\hline 9 & $63-67$ & 1 & $1 \%$ \\
\hline & Total & $\mathbf{1 0 0}$ & $\mathbf{1 0 0 \%}$ \\
\hline
\end{tabular}


Tabel 2. Gambaran Responden Berdasarkan Lama Mengajar

\begin{tabular}{cccc}
\hline No & $\begin{array}{c}\text { Rentang Lama } \\
\text { Mengajar }\end{array}$ & Jumlah & Persentase \\
\hline 1 & $<2$ tahun & 9 & $9 \%$ \\
\hline 2 & $2-5$ tahun & 6 & $6 \%$ \\
\hline 3 & $6-9$ tahun & 5 & $5 \%$ \\
\hline 4 & $10-13$ tahun & 7 & $7 \%$ \\
\hline 5 & $14-17$ tahun & 8 & $8 \%$ \\
\hline 6 & $18-21$ tahun & 14 & $14 \%$ \\
\hline 7 & $22-25$ tahun & 16 & $16 \%$ \\
\hline 8 & $26-29$ tahun & 14 & $14 \%$ \\
\hline 9 & $30-33$ tahun & 17 & $17 \%$ \\
\hline 10 & $34-37$ tahun & 4 & $4 \%$ \\
\hline & Total & $\mathbf{1 0 0}$ & $\mathbf{1 0 0 \%}$ \\
\hline
\end{tabular}

Sementara, untuk lama mengajar, rentang paling tinggi berada pada rentang $30-33$ tahun $(17 \%)$ dan rentang terendah lama mangajar guru berada pada 34-37 tahun (4\%) (Tabel 3). Sedangkan jumlah usia terendah berada pada rentang usia 28 hingga 32 tahun dan 63 hingga 67 tahun (1\%). Untuk jenis kelamin, didapat data sebesar $36 \%$ laki-laki dan $64 \%$ perempuan.
Pada Tabel 4., terlihat gambaran deskriptif data untuk masing-masing variabel. Untuk variabel literasi informasi, mean sebesar 1.4774 dan untuk efikasi guru sebesar 3.3534. Besaran standar deviasi untuk literasi informasi sebesar 1.47184 dan untuk efikasi guru sebesar 1.97342. dan untuk besaran variance sebesar 2.166 untuk literasi informasi dan 3.894 untuk efikasi guru.

Tabel 2. Kategori Skor Fear of Negative Appearance Evaluation

\begin{tabular}{|c|c|c|c|}
\hline Kategori & Skor & Frekuensi & Persentase \\
\hline Rendah & $X<0,36$ & 53 & $49,1 \%$ \\
\hline Tinggi & $X \geq 0,36$ & 55 & $50,9 \%$ \\
\hline \multicolumn{2}{|c|}{ Total } & 108 & $100 \%$ \\
\hline
\end{tabular}

Maka dapat diketahui bahwa respon dengan skor lebih tinggi memiliki persentase yang lebih tinggi yaitu sebanyak 50,9\% dibandingkan dengan responden yang memiliki skor rendah sebanyak $49,1 \%$.

Analisis regresi digunakan untuk mengetahui bagaimana hubungan sebab akibat antar variabel penelitian. Pengujian hipotesis tersebut dilakukan dengan analisis regresi satu prediktor dengan menggunakan SPSS. Pengujian hipotesis dilakukan dengan membandingkan antara nilai $\mathrm{F}$ hitung dengan $\mathrm{F}$ tabel $(1 ; 106)$ dan nilai $\mathrm{p}$ dibandingkan dengan $\alpha=0,05$ untuk menentukan apakah $\mathrm{Ha}$ diterima atau ditolak dengan kriteria Ha diterima jika nilai $\mathrm{F}$ hitung $>\mathrm{F}$ tabel dan nilai $\mathrm{p}<0,05$ yang menyatakan bahwa terdapat pengaruh fear of negative appearance evaluation terhadap citra tubuh pada wanita yang kelebihan berat badan usia remaja akhir sampai dewasa awal di Jakarta.

Berdasarkan Tabel 3, dengan menggunakan analisis korelasi, didapat besar p sebesar 0.000 dengan koefisien korelasi sebesar 0.369 atau $36,9 \%$. Jika hasil $\mathrm{p}$ dibandingkan dengan nilai $\alpha$ sebesar 0,05 , maka $\mathrm{p}<$ dari 0.05 sehingga Ho ditolak. Dengan demikian terdapat hubungan antara efikasi guru dengan literasi informasi pada guru SMA. Besarnya kekuatan hubungan antara efikasi guru dengan literasi informasi sebesar $36,9 \%$ dan arah hubungan antarvariabel bersifat positif, artinya apabila semakin tinggi efikasi yang dimiliki guru dalam mengajar, maka kemampuan literasi informasi yang dimiliki guru juga cen- 
derung semakin tinggi. Demikian juga sebaliknya, jika semakin rendah efikasi guru, maka kemampuan literasi informasi dari guru tersebut juga akan cenderung rendah. Sebagai gambarannya dapat dilihat pada Tabel 4. di bawah ini.

Tabel 3. Data Deskriptif

\begin{tabular}{lcccc}
\hline Variabel & $\mathbf{N}$ & Mean & Variance & SD \\
\hline $\begin{array}{l}\text { Literasi } \\
\text { Informasi }\end{array}$ & 100 & 1,4774 & 2,166 & 1,47184 \\
\hline $\begin{array}{l}\text { Efikasi } \\
\text { Guru }\end{array}$ & 100 & 3,3534 & 3,894 & 1,97342 \\
\hline
\end{tabular}

Tabel 4. Uji Model Summary

\begin{tabular}{|c|c|c|c|}
\hline & & $\begin{array}{c}\text { Efikasi } \\
\text { Guru }\end{array}$ & $\begin{array}{c}\text { Literasi } \\
\text { Informasi }\end{array}$ \\
\hline & Efikasi Guru & 1,000 & 0,369 \\
\hline $\begin{array}{l}\text { Pearson } \\
\text { Correlation }\end{array}$ & $\begin{array}{l}\text { Literasi } \\
\text { Informasi }\end{array}$ & 0,369 & 1,000 \\
\hline Sig. (1-tailed) & $\begin{array}{l}\text { Efikasi Guru } \\
\text { Literasi } \\
\text { Informasi }\end{array}$ & $\begin{array}{c}0 \\
0,000\end{array}$ & $\begin{array}{c}0,000 \\
0\end{array}$ \\
\hline
\end{tabular}

Hasil penelitian ini sejalan dengan teori yang dikemukakan sebelumnya. Muzdalifah dan Listyasari (2013) menjelaskan bahwa guru yang memiliki efikasi yang tinggi mudah terbuka dengan banyak gagasan, sehingga lebih mudah bagi guru tersebut untuk melakukan literasi. Seseorang dengan tingkat efikasi yang rendah juga dapat membatasi seseorang untuk dapat menggali kemampuan dalam melakukan literasi informasi. Hal ini dikarenakan efikasi diri dapat mempengaruhi perilaku seseorang untuk melakukan sesuatu. Jika efikasi yang dimiliki rendah, maka kerelaan atau keinginan seseorang untuk melakukan hal tersebut juga akan berkurang, apalagi jika hal tersebut tergolong dalam kegiatan yang sulit atau menantang. Dalam hal menyelesaikan masalah melalui proses literasi informasi, ketika seseorang merasa bahwa dirinya memiliki kompetensi dan percaya diri dengan kemampuan literasi informasi yang ia punya, ia akan secara sukarela dan bersedia untuk menyelesaikan masalah tersebut (Kurbanoglu, 2010). Begitu pula dalam konteks pendidikan. Jika seorang guru memiliki tingkat keyakinan yang tinggi pada dirinya dalam hal mengajar, maka ia juga akan dengan penuh kerelaan melakukan segala cara untuk dapat menyelesaikan tugas yang diemban- nya dengan baik, salah satunya dengan memaksimalkan kemampuan literasi informasi yang dimiliki.

Penelitian ini mendapatkan responden dengan usia yang lebih banyak berada pada usia dewasa awal dan telah memiliki pengalaman mengajar yang lama. Sebanyak 29\% dari jumlah responden termasuk pada rentang usia 48 hingga 52 tahun. Untuk lama mengajar, sebanyak $17 \%$ dari jumlah responden berada pada rentang 30 hingga 33 tahun. Pada rentang ini, guru telah memiliki banyak pengalaman mengajar yang akan membantu meningkatkan keyakinan mereka terhadap kemampuan mengajar di kelas. Sesuai dengan teori yang dikemukakan Bandura (1997 dalam Tschannen-Moran dan Woolfolk Hoy, 2007) bahwa dari empat faktor yang mempengaruhi tingkat efikasi guru, mastery experience atau pengalaman keberhasilan merupakan faktor yang paling mempengaruhi. Keyakinan terhadap kemampuan yang dimiliki akan meningkat jika guru merasa bahwa kinerja mengajarnya sukses dan akan membuat ekspektasi terhadap kinerja berikutnya kemungkinan akan semakin mahir. Dan sebaliknya, efikasi juga akan menurun jika guru mengalami kegagalan pada kinerja sebelumnya yang mempengaruhi ekspektasi pada kinerja 
berikutnya (Tschannen-Moran \& Woolfolk Hoy, 2007).

Peningkatan dalam efikasi diri dapat menghasilkan usaha dan ketekunan yang lebih besar dari waktu ke waktu dan efikasi yang rendah dapat menghasilkan motivasi dan resiliansi yang menurun pula (Guskey, 1988; Ross, 1998; Tschannen-Moran dkk, 1998 dalam TschannenMoran \& Johnson, 2011). Saat guru merasa bahwa kinerja dalam kelasnya berhasil berturutturut, guru tersebut akan merasa bahwa dirinya cukup terampil dalam mengajar di kelas. Hal ini akan membuat motivasi yang ada dalam diri guru tersebut meningkat yang mana akan meningkatkan usaha yang dikeluarkan. Melakukan literasi informasi dalam hal meningkatkan kinerja guru dalam mengajar juga merupakan salah satu usaha yang dilakukan oleh guru tersebut. Adanya tuntutan berupa susunan kurikulum yang mengharuskan mereka untuk lebih menggali kemampuan literasi informasi juga dapat menjadi salah satu faktor pendukung lain terdapatnya hubungan antara efikasi diri pada guru dengan kemampuan litersi informasi. Bentuk kurikulum 2013 yang menitikberatkan pada eksplorisasi kemampuan siswa, mengharuskan guru untuk lebih menggali semua informasi yang ada. Dengan pengalaman yang dimiliki oleh guru, membuat penggalian informasi yang dibutuhkan secara tepat juga akan lebih mudah. Dengan demikian, semakin tinggi efikasi yang dimiliki guru maka akan semakin tinggi pula tingkat kemampuan literasi informasi guru tersebut.

\section{Kesimpulan}

Penelitian ini ingin mengetahui apakah terdapat hubungan antara efikasi diri dengan kemampuan literasi informasi pada guru sekolah menengah atas. Berdasarkan analisis dan perhitungan statistik dengan uji korelasi bivariat, maka dapat disimpulkan bahwa terdapat hubungan antara efikasi diri dengan kemampuan literasi informasi pada guru sekolah menengah atas. Besarnya koefisien korelasi antarvariabel sebesar 3,69\% dengan arah positif. Hal ini dapat diartikan bahwa jika efikasi diri pada guru semakin tinggi, maka kemampuan literasi informasi pada guru juga akan semakin tinggi.

\section{Daftar Pustaka}

Bandura, A. (1995). Excercise of Personal and Collective Efficacy in Changing Societies. Self-Efficacy In Changing Societies. New York: Cambridge University Press.

Gurcay, D. (2015). Preservice Physics Teachers' Beliefs Regarding Their Teacher Efficacy and Classroom Management. ProcediaSocial and Behavioral Sciences, 197, 1101-1106.

Kurbanoglu, S. (2010). Self-efficacy: An alternative approach to the evaluation of information literacy. Qualitative and Quantitative Methods in Libraries. 1-6

Muzdalifah, F., Listyasari, W.D. (2013). Psikologi Pendidikan 2. Jakarta: Program Studi Psikologi Universitas Negeri Jakarta.

Myers, D.G. (2012). Psikologi Sosial (Aliya Tusyani, Lala Septiani Sembiring, Petty Gina Gayatri, dan Putri Nurdina Sofyan, Penerjemah). Jakarta: Penerbit Salemba Humanika.

Ozder, H. (2011). Self-Efficacy Beliefs of Novice Teachers and Their Performance in the Classroom. Australian Journal of Teacher Education. 36(5), 1-15.

Putri, D.E.. (2015). Pelaksanaan Kurikulum 2013 pada Sekolah Menengah Atas Negeri di Kabupaten Jepara (Studi di Sekolah Menengah Atas Negeri 1 Jepara dan Sekolah Menengah Atas Negeri 1 Tahunan. Skripsi. Semarang: Universitas Negeri Semarang.

Sangadji, E.M., \& Sopiah. (2010). Metodologi Penelitian. Yogyakarta: Penerbit Andi.

Sugiyono. (2014). Metode Penelitian Kuantitatif, Kualitatif, dan R\&D. Bandung: Penerbit Alfabeta. 
Tschannen-Moran, M., \& Hoy, A. W. (2007). The Differential Antecedents of SelfEfficacy Beliefs of Novice and Experienced Teachers. Teaching and Teacher Education. 23. 944-956.
Tschannen-Moran., \& Johnson, D. (2011). Exploring Literacy Teachers' SelfEfficacy Beliefs: Potential Sources at Play. Teaching and Teacher Education. 27, 751-761. 